\title{
Of Horsemen and Hermits: Mongolia, North Korea, and the New Security Architecture in Northeast Asia
}

\author{
By Stephen E. Noerper, Ph.D. (USA)
}

The late March 2002 gathering of national leaders in Monterrey, Mexico saw repeated emphases on the need to rectify economic disparities in the international arena and assist the world's poor. Having announced a planned increase in US overseas assistance prior to the event, US President George W. Bush linked poverty alleviation with anti-terrorism. The argument, as previously articulated by US Secretary of State Colin Powell, is one where economic equity provides hope, eliminating hotbeds of disenfranchisement and dissent. The elevation of economic security and new emerging threats reveals a growing consensus toward more effectively addressing the disequalibrium associated with globalisation.

Concurrently, the US President has couched traditional security concerns anew, with weapons of mass destruction a primary focus. The US State of the Union address posited the now (in)famous "axis of evil," comprised of North Korea, Iran, and Iraq, as the principle offender that could afford terrorists new and dangerous capabilities.

When scouring the Northeast Asian landscape, then, one sees a region whose international relations - relatively unwavering this past half centuryare increasingly in flux. The "axis" address elevated North Korea in the broader US strategic calculus, while at the same time limiting the possibility for forward progress in bilateral relations. The anti-terrorism campaign has altered socalled great power relations, seemingly bringing Moscow, Beijing, and Washington into closer proximity, while at the same time masking real and longer term differences. It has also elevated the importance of smaller and middle level powers in the strategic calculus. And the new focus on rectifying the negatives of globalisation suggests a need to focus on the poorer areas of Northeast Asia-Mongolia, North Korea, and Russian Far East - to strike a better distribution of resources and peaceful development. A prosperous region portends a more stabile one. 


\section{Mongolia}

Those who question the strategic relevance of Mongolia might do well to consider the degree of global focus on Afghanistan prior to the events of Autumn 2001. Like Afghanistan, Mongolia sits as a "straddle" country, in its case couched between Russia and China, Northeast and Central Asia, the Islamic and non-Islamic East. The combined size of Britain, Germany, and France, Mongolia is rich in natural resources, largely untapped. With large natural resources and ready access to Siberia, it holds importance to those looking for energy resources for a rapidly developing Northeast Asia. Though challenged in its economic progress a decade after casting off its Stalinist bindings, Mongolia is now seventy-two percent privatised - a nation on the rise, one transforming and transformed, and one kindly disposed to Japanese, Korean, and other economic interests. In labelling last year the Year of Foreign Investment, Mongolia hoped to attract new partners and new financing.

Inhibiting the reform process, however, are struggles in the political arena. Although the former communists are again in control, the ruling Mongolian Peoples Revolutionary Party considers itself a democratic one and harbours both progressive and conservative elements within. Its control of 72 of 76 parliamentary seats suggests to some observers stasis, but the degree of factionalism is on the rise. The opposition for its part remains largely divided, although the potential merger of opposition party elements suggests some fluidity in political restructuring. For all its limits, the political system is one in flux, and the evolution of party politics, institutions, and roles of the parliamentary, judicial, and executive branches suggests an ultimate move forward on the road to democracy. One might liken the diversity and political debate in Mongolia today as not dissimilar to that in a newly democratised Seoul in the late 1980s.

Mongolia is on a seeming rise in the broader strategic calculus as well. Largely forgotten in the decade since its transition to democracy, Mongolia has emerged as a focus in Chinese and Russian discussions on Northeast and Central Asia. Russian President Putin visited in November 2000, signalling a growing role for Mongolia in his look eastward. His visit followed on that of Chinese, South Korean, and Japanese leaders the year prior. Late March 2002 saw a visit by the Russian Prime Minister to Ulan Bator. Both Russia and China have discussed the possible role of Mongolia in the Shanghai Cooperation Organization ( $\mathrm{SCO}$ ), the Central Asian alliance aimed at countering terrorism. This calculus increased in importance with growing Chinese and Russian concerns 
about longer term US involvement in Central Asia. China, for its part, maintains a critical and growing economic interest in Mongolia and received Mongolia's Prime Minister in early January 2002 for a discussion of expanding bilateral relations. Chinese President Hu Jin-tao's 2003 state visit to Mongolia signalled further dynamism in bilateral relations.

Mongolia's relations with China and Russia are complicated as well. China has largely undercut the Mongolian cashmere industry and is the source of a large pool of illegal labour. Mongolians also harbour a distinct distrust of China, born of history. Mongolians, trustful of Russia, which left infrastructure and services after decades of presence in Mongolia, are increasingly cautious of Russian designs. These are most recently articulated in Russian pressures on Mongolia over property in Ulan Bator and the outstanding debt issue.

Mongolia has actively promoted a third neighbour policy favouring Europe, the United States, and other external actors the last half decade. Europe has been active in Mongolian development circles, particularly through international organizations, Danish assistance in media and other development, and German development and interparliamentary assistance. The Dutch finance minister recently visited Ulan Bator with promises of enhanced support.

In dealing with the United States, Mongolia was quick to offer support for the US anti-terrorism campaign: political statements of condolence and support, overflight of its western provinces for anti-terrorism related military flights. Mongolia's management of its Muslim minority in the west also proves instructive to those seeking a bridge to Islamic Asia.

Aside from its positive response on anti-terrorism, Mongolia has engaged increasingly with the United States in its pursuit of trade and investment. It is also a resource on and contact with North Korea - a valuable asset for the US and others concerned with DPRK developments. Pyongyang and Ulan Bator have a longstanding political relationship that has seen an uptick since a Mongolian foreign ministry delegation visit in late September, a renewed friendship treaty, reestablishment of DPRK representation to Ulan Bator (which had gone into hiatus in 1999 out of economic concerns), the opening of a small DPRK trade office in Ulan Bator, and an airlift of food aid from Mongolia to North Korea after autumn 2001 floods in the DPRK's eastern provinces.

Mongolia, which has enjoyed burgeoning political and economic relations with South Korea this last decade, has also emerged as a key facilitator for North Korean refugees making their way to the South. US Korean American aid groups working with DPRK refugees estimate that some 500 of the 
approximately 580 North Koreans who wound up in Seoul in 2001 transited through Mongolia - a figure, if accurate, that is far higher than any previously estimated by western governments.

Mongolia views itself as a potential mediator in Korean peninsular affairs, especially given its good relations with both Pyongyang and Seoul and historic, linguistic, and ethnic ties. South Korean small business is on the rise in Mongolia. And Mongolia, with a decade of transitional experience from a Stalinist system, may well have much to offer the peninsula.

\section{North Korea}

The DPRK for its part find itself in a difficult position, especially given what it perceives as US hardline policy and overt dislike by the US President for North Korean leader Kim Jong Il, particularly relevant in the context of Confucianism and the cult of Kim. Pyongyang felt that it was drawing closer to normalization with the Americans toward the end of the Clinton administration, but were alarmed by the Bush policy review and its wake. The "axis address" and ensuing expressions of "disdain" eliminated room for dialogue and ran the risk of cornering the regime in Pyongyang.

Filling the void for the US during its policy review was an active European Union (EU), then under Swedish presidency. Swedish PM Persson's EU troika visited Pyongyang in May 2001, historic in terms of western penetration and given Kim Jong Il's personal reception of the group. The visit followed an active two years of relations between North Korea and individual European nations. Italy had set normalization into play in early 2000, with 13 of $15 \mathrm{EU}$ nations following in its stead. Kim Dae Jung's Nobel addresses in Stockholm and Oslo had called for greater engagement with the North, and the EU rose to the occasion, spiriting efforts at a time when the DPRK's slowdown with the United States had cast a shadow on the South Korean President's Sunshine policy. Although subsequent meetings between the EU and DPRK have seen slow-going on human rights and missiles, the March 3-15, 2002 visit by a senior DPRK economic delegation suggests interest in European economic models and possibilities for further exchange and training. Sweden, among other EU nations, also provides a valuable setting for dialogue and other confidencebuilding measures.

Recent concerns about DPRK nuclear ambitions are justified. But the DPRK also has expressed a willingness to entertain reform, although not by that name, seemingly strengthened in the aftermath of Kim Jong Il's visit to 
Shanghai, and exposure to EU economies, banking and other regulation mechanisms, and information technology policy may register with pragmatists in Pyongyang. Although signs of any real economic progress are invisible, the DPRK leadership has voiced enthusiasm for IT and sent a cross-sectional representation in its recent visit that signalled a surprising breadth of DPRK bureaucratic and party interest in the EU.

The importance of EU assistance rises given not only the DPRK's stalled relationship with the Americans, but the more conservative strain in Japan's relations with the North as well. Japan halted its food aid to the North last year, and ongoing concerns about Japanese kidnapped by the North in the 1970s, a purging of the credit unions run by pro-DPRK Koreans in Japan, and the sinking of a DPRK spy vessel by Japan in Chinese territorial waters speaks to the downgrade in relations. The DPRK ferry link was halted by North Korea in June 2003. The DPRK's August 1998 missile test over Japan, in conjunction with the kidnapping issue and visit of Japanese wives from North Korea to Japan, constituted a watershed in shifting Japanese perceptions of the DPRK; in years prior the Japanese public has expressed an ambivalent but somewhat equidistant attitude toward the Koreas. That public attitude toward the North has transformed into fundamental distrust. Recent political scandals and resignations in Japan and the Prime Minister's decline from ninety to fifty percent popularity ratings suggest that the domestic mood in Tokyo will be even more unforgiving with the DPRK, despite official reassurances to Seoul of its support for South Korean President Roh's approach.

Russia and China have upgraded relations with North Korea. The DPRK's Kim Jong Il visited Russia for three weeks in summer 2001, demonstrating both the North Korean leader's consolidation of leadership (in feeling safe to leave home for so long a time) and renewed interest in dealing with Moscow on political, economic, and military matters. Kim's terminus was in St. Petersburg, a window on Europe. Kim's visit followed two trips to China in as many years. China's Jiang Zemin in turn visited Pyongyang in September 2001, signalling China's continued interest and critical role on the peninsula. Although the levels of Russian and Chinese support for Pyongyang are unlikely to mirror that in the Cold War, it is clear that both Moscow and Beijing have upgraded relations with Pyongyang, in part as a point of leverage for their dealings with the United States. 


\section{New Security Architecture in Northeast Asia}

Evident in Northeast Asia then are arrangements in flux, with Russia reasserting itself eastward in both Mongolia and North Korea. China is on the rise-economically, politically, and in terms of its military capability. Its grappling with SARS suggested new demands and accountability on the part of Beijing's leadership. Japan is seeking a more "normal" status, with its and South Korea's autonomous capabilities increasing. Japan's sinking of the DPRK spy vessel was historic as the first demonstration of live fire since World War II. The United States remains forward deployed - the DPRK the underscored raison d'etre - but questions will persist about the scope, impact, shape, and longevity of US force presence; a decline in threat perceptions associated with the DPRK would necessitate new justifications for US forward presence. The US is already describing anticipated pullbacks from the DMZ and force restructuring and redeployment elsewhere. Economic challenges abound throughout the subregion, complicating political and security perceptions. And terrorism, environmental concerns, and energy security have emerged as nontraditional priorities.

Nobel laureate Kim Dae Jung called for a new security architecture for the peninsula and subregion. Although the negative turn of attitudes in Washington and Tokyo impeded his administration's efforts with the DPRK, that new architecture is emerging regardless and will continue under Roh, his successor. Economic and new security concerns will define the agendas among states in Northeast Asia.

Consistent with Japanese track two calls for a "grand design," or more coordinated and synergistic approach toward subregional economic development, a new Northeast Asian architecture need recognize the inherent capabilities of all national actors and take advantage of burgeoning provincial and local contacts among Northeast Asians. Japanese and South Korean ODA need combine with management and technology inputs, and the nations of the "north," such as Mongolia and North Korea should be recognized in terms of both need and resources at hand.

In an area largely defined by strong bilateral relations the past half century, the emerging architecture will have to avail itself of the multilateralism prevalent since the mid-1990s and enhanced (despite fears of US unilateralism) since 911. The notion of community of nations gained special impetus with the tragic events of September in that common threats and common concerns may be remedied only by common solutions. 
How might the international community further then developments in the region? One is an upgrade in the recognition and strategic calculus of poorer nations, such as Mongolia. When one sees the 160 internet cafes on offer in Ulan Bator or addresses Mongolia's cosmopolitan and intellectually keen young people, one sees a dynamism, a nation seeking to bridle the forces of globalisation but at risk of being left behind without an international community leg-up. What is required is not only an upgrade in assistance but a political commitment to applaud and reinforce positive developments in reforming societies like Mongolia.

Similarly, the international community need recognize that the "last of the Leninists"-North Korea-is at the core a strategically challenged and impoverished nation. The fine line is in softly encouraging positive reforms where they might occur - through contacts by aid organizations at the local and provincial levels, through sponsoring study and training missions that fundamentally alter DPRK expectations and provide necessary exposure and skills - while at the same time not rewarding "bad" behaviour — brinkmanship or unreasonable demands.

In essence, the international community needs to reward and foster the horsemen, not the hermits, and bring to the table those attempting to raise standards of living at home. For Mongolians, that viability lies too with exchange and training opportunities abroad, reminding Mongolians that the difficult road to transition is one that can be facilitated by the outside. Similar efforts need continue to occur with the North Koreans, but not at the expense of those nations seemingly less relevant to the immediate strategic calculus. Missiles and weapons of mass destruction do warrant swift attention, but capabilities need not be overstated and limitations should be recognized. At the same time, nations such as Mongolia, which declared itself a nuclear free zone, should be applauded and lessons learned applied to the peninsula; this type of initiative will gain in relevance as the peninsula moves toward integration and unification.

A Seoul connected to Ulan Bator by rail, a mere 20 hour journey, suggests a fundamental economic transformation in Northeast Asia, one where energy and natural resources will help feed Chinese, Korean, and Japanese demands, and where Japanese and South Korean investment, management, and technology can help remedy poverty in the "north." The natural economic territory suggests tremendous opportunities for prosperity in the region. That institutions and new security architecture facilitate peace with prosperity is key; that the horsemen of the "north" share in regional development is essential. 
Dr. Stephen Noerper is the Senior Analyst and Managing Editor at Washington's Intellibridge Corporation. He has served with The Asia Foundation, US Department of State, Asia Pacific Center for Security Studies, East-West Center, Nautilus Institute for Security and Sustainable Development, and Edward R. Murrow Center for Public Diplomacy. Dr. Noerper also served as visiting professor to Japan's Waseda University (2002-2003) and the National University of Mongolia (2000-2001) and as visiting scholar to South Korea's Institute for Foreign Affairs and National Security. He is a graduate of the Fletcher School of Law and Diplomacy and the London School of Economics. Professor Noerper is widely published and appears frequently in media. 